\title{
Jane Gaskell and Ben Levin Making a Difference in Urban Schools: Ideas, Politics and Pedagogy
}

Toronto: University of Toronto Press, 2012. 219 pp.

\section{Charles Ungerleider}

The University of British Columbia

A contemporary of the authors, I, like many of our generation, came to teaching imbued with the desire to make a difference. We baby-boomers were animated by the promise of schooling in a democratic society: namely, that the outcomes one achieves as a consequence of one's education should not be limited by who one is or with whom one lives.

In Making a Difference in Urban Schools, Gaskell and Levin use the cities of Winnipeg, Manitoba and Toronto, Ontario as vehicles to explore the ideas, politics, and pedagogy current between 1970 and the present. Winnipeg and Toronto - and, in fact, the entire volume - are a vehicle for Gaskell and Levin to consider the issues that have animated us for most of our professional lives.

Knowing this is crucial to anyone looking for hard data in the account that Levin provides of Winnipeg and Gaskell provides of Toronto. These are interpretive and artful reconstructions of the past. It is equally important for readers to recognize that drawing strong inferences from such accounts is difficult, if not impossible. That's why Gaskell and Levin call their summary interpretations "lessons." They are as much lessons about school reform as they are about the beliefs and values of the authors who have spent their professional careers working assiduously for educational and social equity.

According to the authors' account, the study began out of "social and political conviction" (7) and was executed in what they hoped was a balanced and analytical manner. Their account brings dignity to the significant efforts of the educators and community activists whose work was always less successful than they wished, given what Gaskell and Levin refer to as the "scope of their ambitions" (7).

Drawing — often selectively — upon the evidence they adduce from their accounts 
of schooling in these two Canadian cities, the authors fashion lesson that they propel beyond the evidence through their understanding of the history and sociology of education. The first lesson they draw about school improvement over the last 40 years is that the more things change, the more they remain the same. Well, not exactly the same, but mostly. Educational and social inequalities remain, even though the entire distribution of school outcomes has shifted in a more positive direction. Student performance has improved dramatically in Canada over the period. Graduate rates have increased. Both the proportion and the number of graduates progressing to post-secondary education have increased.

Nonetheless, the gaps in educational attainment remain. Students from some ethno-linguistic groups and Aboriginal students are the most visible evidence that the promise of schooling in a democratic society goes unfulfilled for too many.

Gaskell and Levin show that ideas matter to how society regards and engages with its schools. The same spirit that animated us in British Columbia animated the work of the educators and community activists in Winnipeg and Toronto. Inspired by the women's movement, anti-racism, and the social movement against the Vietnam War, baby-boomers increasingly saw schooling as a vehicle for social change.

Though school effects and effectiveness may have been overstated, there is little doubt that, in general, outcomes have improved. Students are better treated and better educated than at any time in the past. And, given that Canadian schools are more diverse than at any previous time and are better at retaining students until they graduate, the improvements are remarkable.

The authors inject research into the discussion of ideas, though its treatment is more rhetorical than descriptive. Noting that research can play a part in helping to shift public or professional thinking, they argue that "educators should embrace research and data as a key part of their practice" (183). The juxtaposition of research and ideas came perilously close to advocating science in the service of ideology through reference to think tanks and interest groups that commission research in order to influence public policy.

Another lesson drawn is that education is inevitably political. Politics is an inevitable consequence of scarcity. The time available for schooling is more limited than what society might wish its schools to accomplish, engendering competing claims that can only be resolved through the political process.

Gaskell and Levin conclude the volume with a discussion of elements important to the ability of urban districts to provide good education:

1. School districts with clear, well-founded, plans;

2. Productive links between large urban districts and provincial governments;

3. More public debate based upon data on the political controversies inherent in urban public education;

4. Urban schools as good place to work and learn, so as to attract and retain skilled and dedicated educators;

5. A central and sustained focus on improved teaching and learning;

6. Stronger and consistent community engagement; 
7. Better use of research and evidence; and

8. The necessary infrastructure to support all of the above (193).

They assert that the list is derived from the Winnipeg and Toronto cases and from the broader literature.

The elements are certainly interesting and worthy of consideration, but it is a stretch to say they were derived from the cases or the literature. The elements and their discussion tell us as much about Gaskell and Levin as they do the literature, Toronto or Winnipeg. There is nothing wrong with that, but Gaskell and Levin's claim about being evidence- and literature-informed seems a bit out of place to me.

Notwithstanding this reservation, there are good reasons to consider seriously what the authors have written. First, the book provides insight into the values and predilections of Gaskell and Levin, scholars whose work has influenced Canadian education over the period covered by the book. Second, the book affirms the work of educators and activists on behalf of social and educational equity, bringing dignity to their efforts and those values, and reaffirming their importance. Third, the book is a compendium of ideas about public schooling, community, politics and the intersections among them worthy of attention by every citizen concerned about the state of Canadian public schooling. 